\title{
Cadres Outreach Program to Mothers Improve Nutritional Status of Under Two Year Old Children \\ by Martha Irene Kartasurya
}

Submission date: 13-Dec-2019 04:09PM (UTC+0700)

Submission ID: 1233782483

File name: 2.pdf (1.31M)

Word count: 3574

Character count: 18594 


\title{
Cadres Outreach Program to Mothers Improve Nutritional Status of Under Two Year Old Children
}

\author{
Martha Irene Kartasurya ${ }^{1}$, Dina Rahayuning Pangestuti ${ }^{1}$, Aditya Kusumawati ${ }^{2}$, Resa Ana Dina ${ }^{3}$, \\ Julia Pertiwi ${ }^{4}$, Doddy Izwardy ${ }^{5}$, Anung Sugihantono ${ }^{6}$ \\ ${ }^{\prime}$ Public Health Nutrition Department, ${ }^{2}$ Health Education and Behavioral Science Department, \\ ${ }^{3}$ Environmental Health Department, Faculty of Public Health, ${ }^{4}$ Master's Program in Epidemiology, Post \\ Graduate School, Diponegoro Univer 2 ty, Semarang, Indonesia, 50275; ' Director of Community Nutrition, \\ ${ }^{6}$ Director General of Public Health, Ministry of Health Republic of Indonesia, Jakarta, Indonesia, 12950
}

\begin{abstract}
After exclusive breas 1 eding,period, complementary feeding is the key elements for under two year old children growth. The lack of nutritious complementary feeding can result in growth failure. This research aimed to improve the nutritional status of under two children through cadre 1 outreach to mothers in providing nutritious complementary food. This quasy experimental study was done at the working area of Puskesmas Genuk, Semarang City, Indonesia. Forty pairs of mother-children under-two in each of 1 ro neighborhood area were recruited in the study, as the intervention and control groups. Thirty four pairs in the intervention group, and 32 pairs in the control group finished the study. Ten cadres were trained in providing nutritious complementary feeding foods practices for under-two children. Every cadre outreached 2 mothers in the intervention group for two month period. Data collection was conducted by interviews using strucipred questionnaires. Weight measurements were done at baseline and at the end of the study. Preceding the study, the average age, weight, WAZ (weight for age Z scores), breastfed status, socioeconomic status between the groups were comparable, but not for gender. There were higher weight changes $(0.4 \pm 0.31$ vs $0.2 \pm$ $0.19) \mathrm{kg}$ and WAZ $(0.1 \pm 0.95$ vs $-0.2 \pm 0.18)$ in the intervention compared to the control group. After controlled for gender, WAZ change was still better in the intervention group. There was no difference in mothers' knowledge on nutrition, but there were better attitude toward nutritious feeding practice, better food preparation sanitation and feeding practice scores in the intervention group after two months. It was concluded that cadres' outreach to the mothers for two months increased growth of under two year old children through a better complementary feeding practice and food preparation sanitation.
\end{abstract}

Keywords: complementary feeding, outreach, cadre, WAZ, feeding practice

\section{INTRODUCTION}

Stunting prevalence was very high in Indonesia. Riskesdas data showed that the prevalence of stunting was $37.2 \%{ }^{1}$ Although it has already decreased in 2018 to $30.8 \%$, this level was still to high. ${ }^{2}$ Studies has shown that stunting prevention was the most sensitive if it was

\section{Corresponding Author:}

Martha Irene Kartasurya

Public Health Nutrition Department,

Faculty of Public Health, Diponegoro University, J1. Prof. Soedarto, SH,Tembalang, Semarang, 50275

Email: marthakartasurya@live.undip.ac.id done during the first 1000 days of life. ${ }^{3,4}$ In Indonesia, intervention during pregnancy has been done through some programs, however many problems still occurred, thus the low birth weight still a problem. Therefore, to prevent stunting, intervention to children after deliveries until two years old should be done to prevent stunting, as this is the best time to do the intervention. ${ }^{5}$ Furthermore the growth of under two children will also affect the longitudinal growth after this period. ${ }^{6}$

Studies has shown that outreach and education program are needed, instead of supplementation only, for the women in urban area, to improve the nutritional status of the children. ${ }^{7}$ Therefore this study will be conducted through an outreach program. Moreover, to 
increase the nutrition program sensitivity, empowerment to the community is one of the key factors. ${ }^{8}$ Therefore, this study was conducted through training the cadres, who were part of the community. The cadres then empowered the the mothers of under two children through an outreach program. The nutritional status improvement was the target of the study.

\section{METHOD}

This quasy experimental study was done in the working area of Genuk Primary Healthcare Center, Semarang, Central Java, Indone 3 . Eighty pairs of mothers and their under two year old children were recruited from the posyandu in two areas of neighborhood (40 pairs in each group), which has the similar characteristics in general. One area was chosen as the 3 tervention group and the other area was us 3 as the control group. At the end of the study, 34 pairs in the intervention group and 32 pairs in the control group stayed in the study. They were followed up for two months after the intervention started.

In the intervention groups, the mothers were outreached by health cadres. The health cadres were gathered and trained by the researchers. They were taught about the importance of nutrition for the health of under two children, what are the nutrient requirements for under two children and how to give them nutritious food, including the recipes and demonstration on how to cook complementary feeding to under two children. They also received handbook about the training materials. Then, they were asked to gathered the mothers once a month to provide them with communication, information and education about nutrition for under two children, including the demonstration on how to cook several nutritious complementary feeding for under two year old children. Every health cadres also visited two pairs of mother and child every week to follow up the message and look after the growth of the children, in the first month. After that, they were visited every months. If the mothers had questions regarding the nutrition, health cadres tried to help with their knowledge. The control group did not received this kind of intervention.

At the beginning of the study, data on characteristics of the subjects were gathered by interviews to the mothers using structured questionnaires. Data on food consumption were also gathered during the study. At baseline, one month and two months after the intervention, anthropometric measurements on weight and height were also done. Children weight were weighed by a digital scale until the nearest 0.1 $\mathrm{kg}$ in a standardize procedures. WAZ scores were then calculated using WHO Anthro calculator software. Some additional variables related to feeding practice behavior were also collected at the end of the intervention. The additional variables included mother's knowledge about nutrition and complementary feeding, maternal attitudes in feeding, frequency of feeding each day, hygiene and feeding practice.

Then, data were checked on their distribution. After cleaning and coding, data were compared between baseline and after the intervention in each group and the changes between the intervention and the control groups. Data on weight at baseline was normally distributed, but weight at after intervention and weight changes were not normally distributed. Independent t-tests were used for comparing normally distributed data and Wilcoxon test were used for non normally distributed data. Chi square tests were used for comparing categorical data. Logistic regression was also used for controlling the WAZ score changes by gender difference between the groups.

\section{RESULTS AND DISCUSSIONS}

The characteristic data in the intervention and control groups were listed in Table 1. There was no difference in age, mothers' education level, mothers' working status, family income and breastfed status between the groups. However, the control group has more boys, while the intervention group has more girls.

Table 2 shows the weight and WAZ scores of the subjects at baseline. There was no difference weight and WAZ between the groups at baseline. Thus, the subjects were at the same condition at the beginning of the study.

Table 3 shows the weight and WAZ Scores data after 2 months of intervention in the intervention and control groups. There were significant difference between the groups in weight after the intervention, but not in WAZ scores. The control group had higher weight compared to the intervention group.

Table 4 shows the comparison between the groups 3 weight and WAZ score changes. The weight changes in the intervention group was higher than the control group. WAZ scores was decrease in the control group, but increase in the intervention group. In these period of 
age, (6 to 24 month old) studies showed that children in low and middle income countries were delivered at low WAZ and falters until 2 years old. Thus, the window of opportunity for intervention is at this age. ${ }^{5}$ Thus, without intervention, WAZ scores of the children in Indonesia generally decrease. The intervention should be done before 2 years old to prevent decrease in WAZ scores which in turn will also lead to a decrease in HAZ scores.

Table 1: Characteristics of the subjects

\begin{tabular}{|c|c|c|c|}
\hline Variables & Control $(n=32)$ & Intervention $(n=34)$ & p-values ${ }^{s}$ \\
\hline Mean age (months) & $12.6 \pm 3.81$ & $14.2 \pm 5.02$ & 0.204 \\
\hline \multicolumn{4}{|l|}{ Sex } \\
\hline Boys & $17(53.1)$ & $11(32.4)$ & \multirow{2}{*}{0.048} \\
\hline Girls & $15(46.9)$ & $23(67.6)$ & \\
\hline \multicolumn{4}{|l|}{ Mothers' education level } \\
\hline Junior High or lower & $5(40.6)$ & $4(22.7)$ & \multirow{2}{*}{0.543} \\
\hline Senior High School or higher & $27(59.4)$ & $18(77.3)$ & \\
\hline \multicolumn{4}{|l|}{ Mothers' working status } \\
\hline Working & $7(36.8)$ & $4(18.2)$ & \multirow{2}{*}{0.161} \\
\hline Not working & $12(63.2)$ & $18(81.8)$ & \\
\hline \multicolumn{4}{|l|}{ Family's income } \\
\hline Lower than regional minimum level & $18(56.3)$ & $11(50.0)$ & \multirow{2}{*}{0.430} \\
\hline The same or higher than regional minimum level & $14(43.7)$ & $11(50)$ & \\
\hline \multicolumn{4}{|l|}{ Breastfed status } \\
\hline Not breastfed & $9(28.1)$ & $8(30.7)$ & \multirow{2}{*}{0.478} \\
\hline Breastfed & $23(71.8)$ & $26(69.2)$ & \\
\hline
\end{tabular}

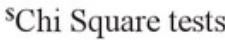

Table 2: Anthropometric status of the subjects at baseline $(n=66)$

\begin{tabular}{|c|c|c|c|}
\hline Variables & $\begin{array}{c}\text { Control } \\
(\mathbf{n}=\mathbf{3 2}) \\
\text { Mean } \pm \text { SD }\end{array}$ & $\begin{array}{c}\text { Intervention } \\
(\mathbf{n}=\mathbf{3 4}) \\
\text { Mean } \pm \text { SD }\end{array}$ & p value \\
\hline Weight $(\mathrm{kg})$ & $10.6 \pm 2.48$ & $9.8 \pm 2.30$ & $0.118^{\circ}$ \\
\hline WAZ Scores & $0.6 \pm 1.90$ & $-0.1 \pm 1.56$ & $0.434^{\#}$ \\
\hline
\end{tabular}

Independent t-test

"Wilcoxon test

After controlled for gender differences in the intervention and control group, WAZ changes still showed the better in the intervention group. By logistic regression analysis, it was shown that the chance of the subjects in the intervention group to have a positive change in WAZ scores was $39.8 \%$, while the chance in the control group was only $12.25 \%$. Among the boys, the chance to have a positive WAZ score change was $14.3 \%$ while the chance of the girls was $28.9 \%$. The studies in Ethiopia showed that the boys were tent to be underweight than the girls, as the boys were more influenced by environmental stress, compared to the girls. ${ }^{9}$ This study in Indonesia also showed that girls had shown more benefited from the intervention program.

Table 3: Anthropometric status after intervention $(n=66)$

\begin{tabular}{|c|c|c|c|}
\hline Variables & $\begin{array}{c}\text { Control } \\
(\mathbf{n}=\mathbf{3 2}) \\
\text { Mean } \pm \text { SD }\end{array}$ & $\begin{array}{c}\text { Intervention } \\
(\mathbf{n}=\mathbf{3 4}) \\
\text { Mean } \pm \text { SD }\end{array}$ & p value \\
\hline Weight $(\mathrm{kg})$ & $10.8 \pm 2.52$ & $10.2 \pm 2.32$ & $\mathrm{p}<0.001^{\#}$ \\
\hline WAZ Scores & $0.4 \pm 1.92$ & $0.1 \pm 1.27$ & $0.281^{\#}$ \\
\hline
\end{tabular}

Wilcoxon test

Table 5 shows the feeding behaviors of the mothers after the intervention, to find out the reason for weight changes in the intervention group at the end of intervention. Mothers' attitude toward feeding nutritious food to their children were better in the intervention group. The food preparation sanitation and feeding practice scores were also better in the intervention group 
compared to the control groups. Thus the changes in WAZ scores in the intervention group can be explained by the feeding behaviors of the mothers.

In this study, the subjects were at 5 to 12 month year old, and the effect of intervention was measured in weight and WAZ score changes only. The reason for this was the short period of intervention and the underweight was the first sign to show the growth faltering, which started at this age. At 6-7 months, Indonesian infants start to falter their growth and showed in more underweight (32\%), rather than stunting (24\%). ${ }^{10}$ This study also showed that WAZ scores decreased in the control group from $0.6 \pm 1.90$ to $0.4 \pm 1.92$ after two months of follow up, while the intervention group increased their WAZ scores from $-0.1 \pm 1.56$ to $0.1 \pm 1.27$. Therefore intervention at this period of time may prevent or postponed the growth faltering. In the long term, this condition may lead to decrease stunting. As the prevalence of stunting in Indonesia was very high, $37.2 \%$ among underfive children, based on 2013' Indonesian Basic Health
Survey (Riskesdas) and 30.8, based on 2018' Indonesian Basic Health Survey. ${ }^{2}$

The factors associated to underweight in developing countries such as Indonesia, included low birthweight status, low sanitation, ${ }^{11}$ mothers' feeding practice of to their toddlers. ${ }^{12}$ This study also showed that mothers feeding practice in the intervention group was better after the study. Better mothers' feeding practice leaded to the higher intake of energy, protein and micronutrients, which then resulted in higher weight changes in the intervention group.

Regarding the sanitation, food preparation sanitation was also have an impact on nutritional status as the better food preparation sanitation resulted in lower diarrhea problems. ${ }^{12}$ In this study, although diarrhea problem was not measured, but the food preparation sanitation practice was better after the intervention. This condition also explained the better WAZ changes in the intervention group.

Table 4: Comparisons of the increments between the groups $(n=66)$

\begin{tabular}{|c|c|c|c|}
\hline Variables & Control $(\mathbf{n}=\mathbf{3 2})$ Mean \pm SD & Intervention $(\mathbf{n}=\mathbf{3 4})$ Mean \pm SD & p value $^{\#}$ \\
\hline Weight $(\mathrm{kg})$ & $0.2 \pm 0.19$ & $0.4 \pm 0.31$ & 0.027 \\
\hline$\Delta$ WAZ Scores & $-0.2 \pm 0.18$ & $0.1 \pm 0.95$ & 0.048 \\
\hline
\end{tabular}

"Wilcoxon test

Table 5: Mothers' Feeding behavior after the intervention

\begin{tabular}{|c|c|c|c|}
\hline Variables & $\begin{array}{c}\text { Control }(\mathbf{n}=\mathbf{3 2}) \\
\text { Mean } \pm \text { SD }\end{array}$ & $\begin{array}{c}\text { Intervention }(\mathbf{n}=\mathbf{3 4}) \\
\text { Mean } \pm \text { SD }\end{array}$ & p value $^{*}$ \\
\hline Feeding frequency & $3.2 \pm 0.47$ & $3.1 \pm 0.74$ & 0.426 \\
\hline Mothers' knowledge on nutrition scores & $24.4 \pm 4.47$ & $25.6 \pm 5.05$ & 0.223 \\
\hline Mothers' attitude on feeding practice scores & $8.3 \pm 2.64$ & $9.50 \pm 3.79$ & 0.046 \\
\hline Food preparation sanitation scores & $6.1 \pm 2.0$ & $6.9 \pm 1.84$ & 0.038 \\
\hline Feeding practice scores & $6.7 \pm 1.98$ & $8.4 \pm 3.51$ & 0.043 \\
\hline
\end{tabular}

"Wilcoxon test

The children in this study received a low energy and protein before the intervention. In the intervention, good source of protein were introduced and the mothers were motivated to cook their complementary feeding food. In general, the mothers in this study had a good education level. Therefore they can received the information from the cadres very well. This condition leaded the mothers to have more self efficacy to provide the food to their children.
There was no difference in the nutrition knowledge between the groups. However, the mothers in the intervention group had a better attitude and feeding practice to provide nutritious food for their children. A study in Turkey, has also shown that mothers' nutritional knowledge resulted in a better attitude and feeding practice to their children. ${ }^{13}$ Although this study was done on much older children, however, the similar condition 
could also be applied on mothers' feeding practice for toddlers. Another study in Kenya showed almost the same results, in which the knowledge of the mothers did not related to the children nutritional status but the mothers knowledge about the health consequences if they did not follow the dietary recommendation was related. ${ }^{14}$ Thus, improving mothers knowledge, attitude and ${ }_{3}$ eding practice were very important for increasing the nutritional status of their children.

The results of this study also inline with the results of a systematic reviews which showed that maternal counseling alone resulted on the increase in weight of children at these age (6-24 months), thus recommended to be done in developing countries. ${ }^{15}$ This study was done through outreach program by the cadres, which can show an effect on WAZ scores of the children. Thus, the program can be done in a wider area, at least in the urban setting.

The limitation of the study is the limited sample size and the short period of outreach program. Therefore a the larger study and the longer period of outreach program are suggested. The strength of this study was the intervention was given to the cadres, thus the cadres can continue the intervention to the other under two mothers who they met in posyandu. The cadres also have more self efficacy in providing advice to the mothers regarding providing nutritious food to the under two children. Undertwo children are extremely needed for nutritious food for their brain and nerve system development.

The implication of the study: This study can be implemented in a more broader area, by training the cadres and monitoring their work more continuously, so the prevention of stunting and malnutrition can be done.

\section{CONCLUSIONS}

Cadres' outreach program for two months to the mothers of under two children can increase weight and WAZ scores through a better complementary feeding practice and food preparation sanitation.

\section{ACKNOWLEDGEMENTS}

This study was funded through the project of Intervention package on nutrition problem and the implementation of the first one thousand days of life in the middle part of Indonesia, a collaboration work between The Ministry of Health, Republic of Indonesia and Diponegoro University (Agreement no. KM.04.01/2/2283/2017 and No. 3595/UN7.5.9/ $\mathrm{KS} / 2017$ )

The researchers would like to thank the Head of Genuk Community Health Center, all of the health cadres who involved in this study and also all of the subjects in this study. We also would like to thank the enumerators who helped in data collections. Without their help, this study would not be implemented well.

Conflict of Interest: There is no conflict of interest of the researchers regarding the study and the results.

Ethical Clearance: This study has fulfilled the requirement for getting the ethical clearance from the Health Ethical Committee of Faculty of Public Health, Diponegoro University No. 213/EC/FKM/2017.

\section{REFERENCES}

1. Ministry of Health Republic of Indonesia. Indonesia $\mathrm{He}_{2}$ th Profile 2013. Published in 2014. http://www.depkes.go.id/resources/ download/pusdatin/profil-kesehatan-indonesia/ Indonesia\%20Health\%20Profile $\% 202013 \% 20$ $-\% 20 \mathrm{v} 2 \% 20$ untuk\%20web.pdf

2. Ministry of Health Republic of Indionesia. Potret Sehat Indonesia dari Riskesd 2 2018. Published on 2 November 2018. http://www.depkes. go.id/article/view/18110200003/potret-sehatindonesia-dari-riskesdas-2018.html

3. Black MM, Pérez-Escamilla R, Rao SF. Integrating Nutrition and Child Development Interventions: Scientific Basis, Evidence of Impact, and Implementation Considerations. American Society for Nutrition. Adv Nutr 2015;6:852-9; doi:10.3945/an.115.010348.

4. Prentice AM, Ward KA, Goldberg GR, Jarjou LM, Moore SE, Fulford AJ, Prentice A. Critical windows for nutritional interventions against stunting. Am J Clin Nutr 2013;97:911-8.

5. Victora CG, de Onis M, Hallal PC, Blössner M, Shrimpton R. Interventions Worldwide Timing of Growth Faltering: Revisiting Implications for Intervention. Pediatrics 2010;125; 473; DOI: 10.1542/peds.2009-1519. http://pediatrics. aappublications.org/content/125/3/e473.full. 
6. Ross ES, Krebs NF, Shroyer ALW, Dickinson M, Barrett PH, Johnson SL. Early growth faltering in healthy term infants predicts longitudinal growth. Early Hum Dev. 2009 September ; 85(9): 583588. doi:10.1016/j.earlhumdev.2009.06.004.

7. Robbins S, Ettinger AK, Keefe C, Riley A, Surkan PJ. Low-Income Urban Mothers' Experiences with the Supplemental Nutrition Assistance 2 ogram. J Acad Nutr Diet. 2017;117:1538-1553. http://dx.doi.org/10.1016/j.jand.2017.01.008

8. Ruel MT, Alderman H, Maternal and Child Nutrition Study Group. Maternal and Child Nutrition 3. Nutrition-sensitive interventions and programmes: how can they help to accelerate progress in improving maternal and child nutrition? The Lancet. Published online June 6, 2013 http:// dx.doi.org/10.1016/S0140-6736(13)60843-0 https://www.unicef.org/ethiopia/3_Nutritionsensitive_interventions_and_programmes_how_ can.pdf. Accessed on November 2018

9. Tosheno D, Adinew YM, Thangavel T, Workie SB. Risk Factors of Underweight in Children Aged 6-59 Months in Ethiopia. Hindawi Journal of Nutrition and Metabolism Volume 2017, Article ID 6368746, 8 pages. https://doi. org/10.1155/2017/6368746

10. Schmidt MK, Muslimatun S, West CE, Schultink W, Gross R, Hautvast JGAJ. Nutritional Status and Linear Growth of Indonesian Infants in West Java Are Determined More by Prenatal
Environment than by Postnatal Factors. J. Nutr. 132: 2202-2207, 2002.

11. Adhikari D, Khatri RB, Paudel YR, Poudyal AK. Factors associated with Underweight among Under-Five children in eastern Nepal:communityBased cross-sectional study. Front. Public Health December 2017: 5:350, pp. 1-9. doi: 10.3389/ fpubh.2017.00350.

12. Agrina, Omote S, Tsuda A, Okuwa M, Kimura R, Syahrul, Saito R. A study of determining factors of underweight among toddlers in Riau, Indonesia. Journal of Wellness and Health Care 2017. vol. 41 (1), 61-69.

13. Yabancı N, Kısaç I, Karakuş SS. The effects of mother's nutritional knowledge on attitudes and behaviors of children about nutrition. Procedia Social and Behavioral Sciences 116 ( 2014 ) 4477 - 4481. doi: 10.1016/j.sbspro.2014.01.970

14. Debela BL, Demmler KM, Rischke R, Qaim M. Maternal nutrition knowledge and child nutritional outcomes in urban Kenya. Appetite 116 (2017) 518-526. http://dx.doi.org/10.1016/j. appet.2017.05.042

15. Imdad A, Yakoob MY, Bhutta ZA. Impact of maternal education about complementary feeding and provision of complementary foods on child growth in developing countries. BMC Public Health 2011, 11(Suppl 3):S25. http://www. biomedcentral.com/1471-2458/11/S3/S25 
Cadres Outreach Program to Mothers Improve Nutritional Status of Under Two Year Old Children

ORIGINALITY REPORT

$7 \%$

SIMILARITY INDEX
$2 \%$

INTERNET SOURCES
$3 \%$

PUBLICATIONS
$6 \%$

STUDENT PAPERS

PRIMARY SOURCES

1

Submitted to Universitas Diponegoro

Student Paper

2 Submitted to University of Sydney Student Paper

"20th International Congress of Nutrition:

Granada, Spain, September 15-20, 2013",

Annals of Nutrition and Metabolism, 2013

Publication

Exclude quotes

Off

Exclude bibliography
Exclude matches

$<2 \%$ 